\title{
Incidence of cotton whitefly Bemisia tabaci (GENNADIUS, 1889) (Hemiptera: Aleyrodidae) infesting cucumber (Cucumis sativus L.) cultivars with reference to cultivar susceptibilities
}

\author{
Ezz El-Din Abd El-Samea El-Shazly ${ }^{1}$, Khaled El-Sayed Ali ABDEL- \\ ATI $^{2}$, Horia Ali Abd EL-WAHAB ${ }^{3}$, Magda Hashim MANSOUR ${ }^{3 *}$ \\ ${ }^{1}$ Department of Economic Entomology \& Pesticides, Faculty of Agriculture, \\ Cairo University, Giza, Egypt \\ ${ }^{2}$ Department of Vegetable Crops, Faculty of Agriculture, Cairo University, Giza, Egypt \\ ${ }^{3}$ Department of Vegetable Pests Research, Plant Protection Research Institute, Agricultural \\ Research Center, Giza, Egypt
}

\begin{abstract}
Field experiments were carried out in Egypt to investigate the infestation rates of cotton whitefly Bemisia tabaci on five cultivars of cucumbers Cucumis sativus during two consecutive late summer seasons from 11 August to 28 October 2015 and 2016. The susceptibilities of the cultivars to infestation by this pest were examined. The five cultivars - Hayl, Nems, Beit Alpha Zena, Bahi and Wafier - were cultivated on a private farm in Mansheyet Saqqara village, Giza. The results showed that whitefly infestation peaks were high in September and October, but low in November in both seasons. The population densities of Bemisia tabaci eggs, nymphs and adults on all the cultivars were slightly higher in 2015 than in 2016. Numbers of B. tabaci eggs, nymphs and adults rose with increasing the temperatures in both seasons, and mean numbers of nymphs and adults also increased with decreasing RH\% on all the cultivars. The combination of temperature and humidity was an important regulatory factor affecting B. tabaci development. The results of this study showed that high infestation peaks of B. tabaci occurred in September and October of both seasons. The present results were used to classify the degrees of susceptibility of these cucumber cultivars to $B$. tabaci infestation as susceptible (S), low resistant (LR) and moderately resistant (MR). It is important that these degrees of susceptibility be referred to the degree of resistance of each cultivar to insect infestation.
\end{abstract}

KEY WORDS: Cucumber, Cucumis sativus, Population fluctuation, RH\%, Temperature

\footnotetext{
*Corresponding author: magda.hashim@gmail.com
} 


\section{INTRODUCTION}

Cucurbits are important vegetable crops. Among them, the cucumber Cucumis sativus L. is economically one of the most important vegetable crops cultivated in Egypt (HANAFY et al. 2014): it is highly nutritious and can be cultivated under different environmental conditions for both local consumption and export (JIANYU et al. 2016).

The cotton whitefly Bemisia tabaci (GENNADIUS, 1889) is a highly polyphagous pest (ca. 506 host plant species from 74 families) among cucumbers in all of its growth stages, i.e. seedling, flowering and fruiting (BASU 1995). The nymph and adult stages of B. tabaci feed on phloem sap and excrete honeydew, which reduces photosynthesis (VAN DoORN et al. 2015).

B. tabaci transmits the cucumber vein yellowing virus to cucurbitaceous plants, including the cucumber: a single adult suffices to transmit the disease (MANSOUR \& ALMOUSA 2008): ca 15-20 insects/plant caused $55 \%$ infection. $B$. tabaci also transmits the squash vein yellowing virus (SqVYV) (ADKINS et al. 2007).

In Egypt, three population peaks of $B$. tabaci were recorded on cucumber summer plantations: during the second week of May, the first week of June and throughout July (AHMED 1994). A very serious infestation of B. tabaci occurred on cucumber during autumn (SHALABY et al. 2013), while a less serious one took place on spring plantations (ADAM et al. 1997). The population dynamics of some sucking pests on cucumber, including B. tabaci, was affected by daily mean temperature and $\mathrm{RH} \%$, the two most important abiotic factors influencing B. tabaci incidence (AMMAR \& ABOLMAATY 2016). A wide range of cucurbitaceous species were shown to be susceptible to $B$. tabaci infestations (MORENO et al. 1993). The differences between the mean numbers of B. tabaci adults per leaf and different stages (egg and nymph) on cucumber cultivars were recorded to determine the susceptibility of commonly cultivated cucumber cultivars to $B$. tabaci infestation in Egypt (EL-GARHY 2013).

The aim of the present work was to study the population of $B$. tabaci on five cucumber cultivars and its relation with temperature and $\mathrm{RH}$, and then to determine the susceptibility of these cultivars to infestation by this pest. The study was carried out during two consecutive late summer seasons in 2015 and 2016.

\section{MATERIALS AND METHODS}

The field experiments were carried out during the summer seasons in 2015 and 2016 at a private farm in the village of Mansheyet Saqqara, Giza, Egypt, in order to investigate the infestation rate of Bemisia tabaci on five cucumber cultivars, i.e. Hayl, Nems, Beit Alpha 
Zena, Bahi and Wafier. Standard agricultural practices were applied throughout the experimental area, without the use of any pesticides. The experimental area of cucumber cultivars was $1050 \mathrm{~m}^{2}$ divided into 20 plots (each plot was $52.5 \mathrm{~m}^{2}$ ). Each plot contained five rows $70 \mathrm{~cm}$ apart. The cucumber cultivar seeds were sown on 11 August. A complete randomized block design was used for distributing the cultivars in the experimental areas. Four replicates of each treatment were performed.

Samples of 25 leaves/plot were picked at random at three-day intervals from 28 August to 28 October in both seasons. Each sample was kept in a tightly closed paper bag and transferred to the laboratory on the same day for inspection. In order to estimate the infestation of $B$. tabaci, the numbers of eggs, nymphs and adults were counted and recorded. Meteorological data, i.e. maximum and minimum temperatures $\left({ }^{\circ} \mathrm{C}\right)$ and relative humidity (RH\%) in both seasons, were obtained from the Central Laboratory of Agricultural Climate, Egypt. The interaction between these weather factors and the numbers of $B$. tabaci infestations was studied by calculating the correlation coefficient (r) and explained variance (E.V. \%). Classification of the degrees of susceptibility of the cucumber cultivars was based on the general mean number of cotton whiteflies $(\overline{\mathrm{X}})$ and the standard deviation (SD) (CHIANG \& TALEKAR 1980).

The cultivar susceptibility classifications were:

a) highly susceptible (HS) $=$ Overall mean on cultivar $>\bar{X}+2 S D$;

b) susceptible $(S)=$ Overall mean on cultivar between $\bar{X}$ and $\bar{X}+2 S D$;

c) low resistance $(\mathrm{LR})=$ Overall mean on cultivar between $\overline{\mathrm{X}}$ and $\overline{\mathrm{X}}-1 \mathrm{SD}$;

d) moderate resistance $(\mathrm{MR})=$ Overall mean on cultivar between $\bar{X}-1$ SD and $\bar{X}-2$ SD;

e) high resistance $(\mathrm{HR})=$ Overall mean on cultivar $<\overline{\mathrm{X}}-2 \mathrm{SD}$.

The data were statistically analysed using the SAS computer program including the Ftest and simple correlation and regression (SAS Institute 2003). Revised least significant differences (LSD) at the 5\% probability level were used for comparing means.

\section{RESULTS}

\section{Population fluctuations of $B$. tabaci during the summer seasons of 2015 and 2016}

\section{a. Adults}

B. tabaci adults appeared on 7 September 2015 on all the cucumber cultivars tested, where the mean numbers of adults/leaf varied between 0.51 and 1.35 . Thereafter, the population increased during September until the first ten days of October. Peak numbers were reached in September on Hayl, Nems and Bahi, while Beit Alpha Zena and Wafier harboured higher mean numbers in October. The adults disappeared between 22 and 28 


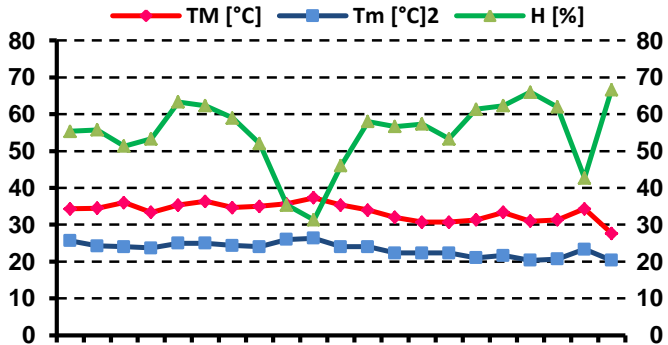

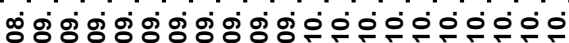

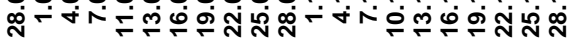
Inspection dates

Wafier

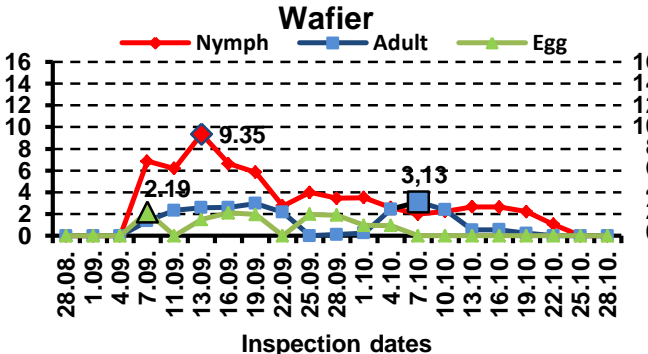

\section{Bahi}

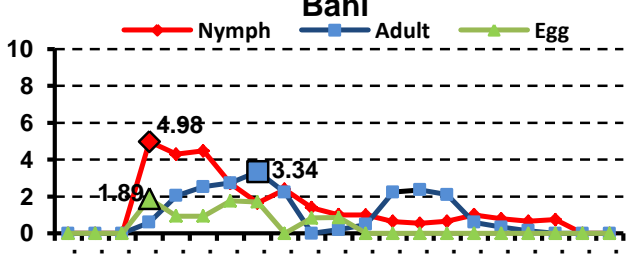

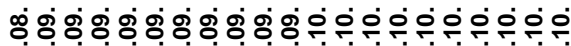

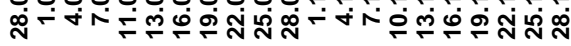
Inspection dates

\section{Beit Alpha Zena}

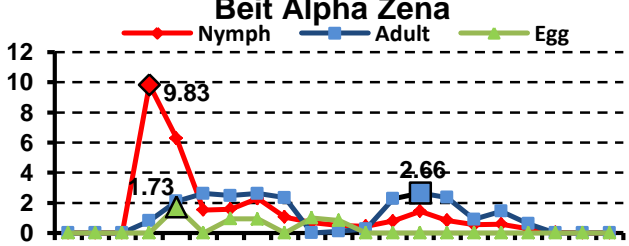

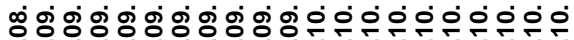
ผู่ + Inspection dates

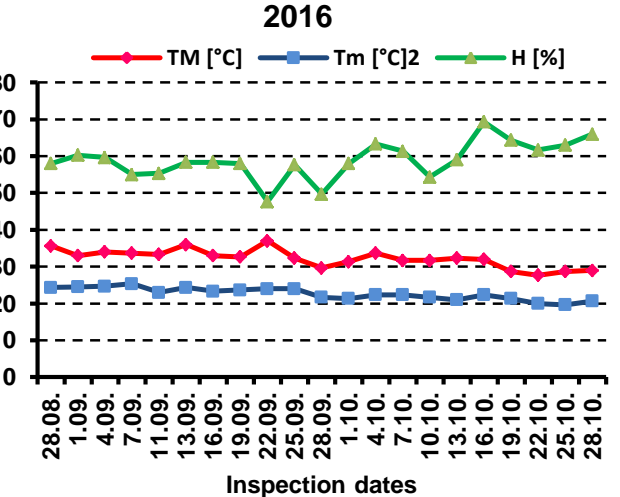

Wafier

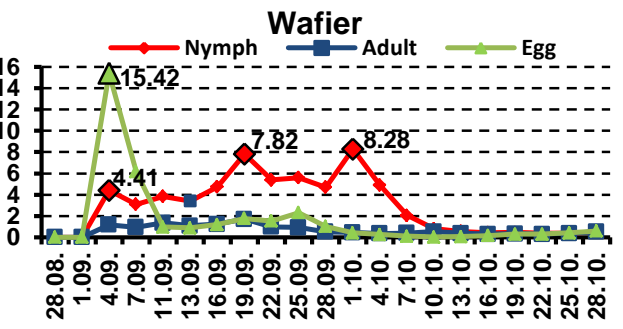

Inspection dates
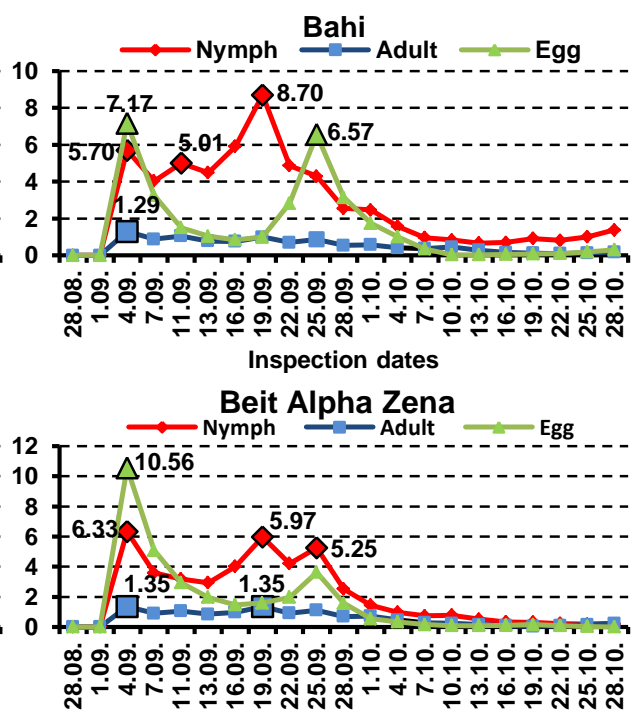

Fig. 1. Mean numbers of Bemisia tabaci eggs, nymphs and adults/leaf on five cucumber cultivars in relation to temperature and relative humidity during 2015 and 2016. TM maxumum temperature, $\mathrm{Tm}$ - minimum temperature, $\mathrm{H}$ - humidity. 


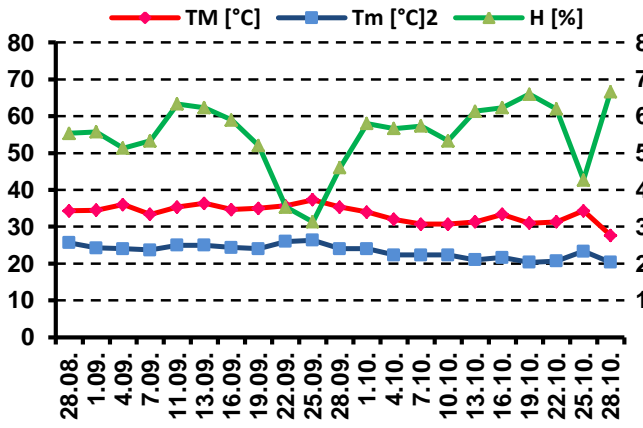

Inspection dates

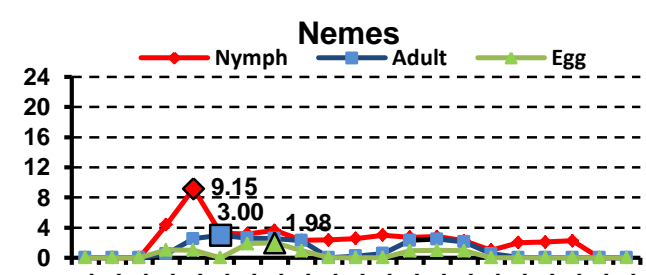
ஜร் ร் த் 穴 Inspection dates

Hayl

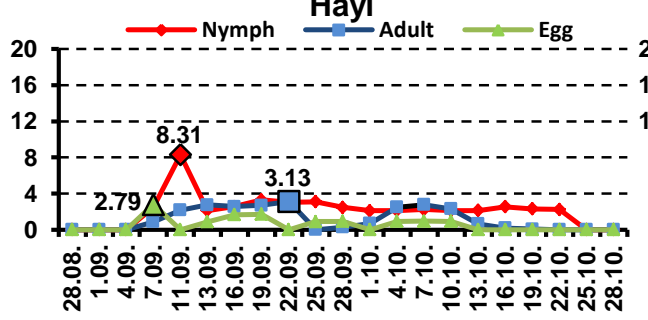

Inspection dates

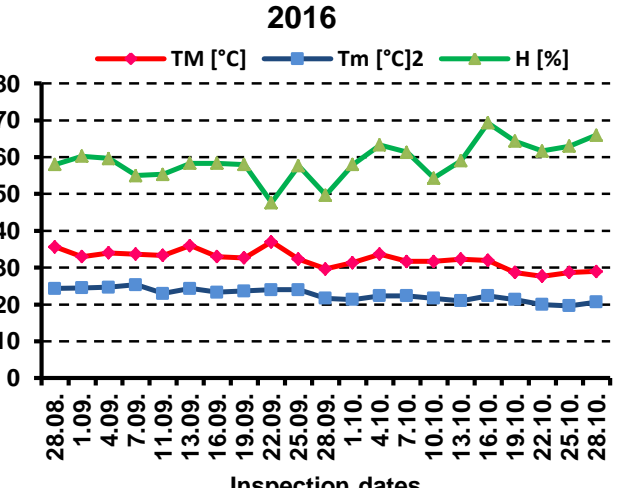

Inspection dates

Nemes

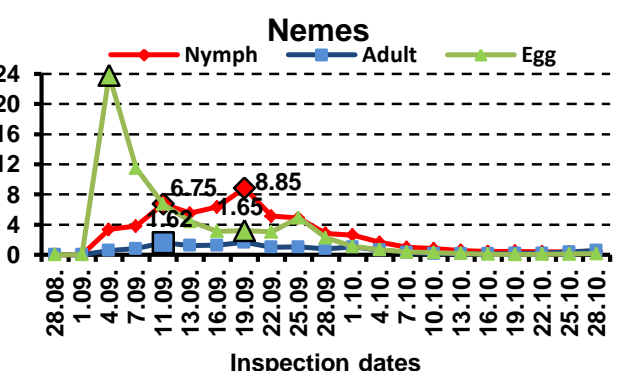

Hayl

Fig. 1. Continued.

October 2015 from all the cultivars (Fig. 1). During 2016, the respective overall mean numbers of adults/leaf on Hayl, Wafier, Nems, Beit Alpha Zena and Bahi were 0.69, 0.66, $0.65,0.55$ and 0.51 (Fig. 2). The results demonstrated that three peaks were recorded in September on Hayl, Nems and Wafier. Four peaks were detected only on Beit Alpha Zena, the highest one (1.35 adults/leaf) being in September 2016. Five peaks of B. tabaci adult infestation were recorded on Bahi, the highest one (1.29 adults/leaf) being on 4 September 2016 (Fig. 1). 

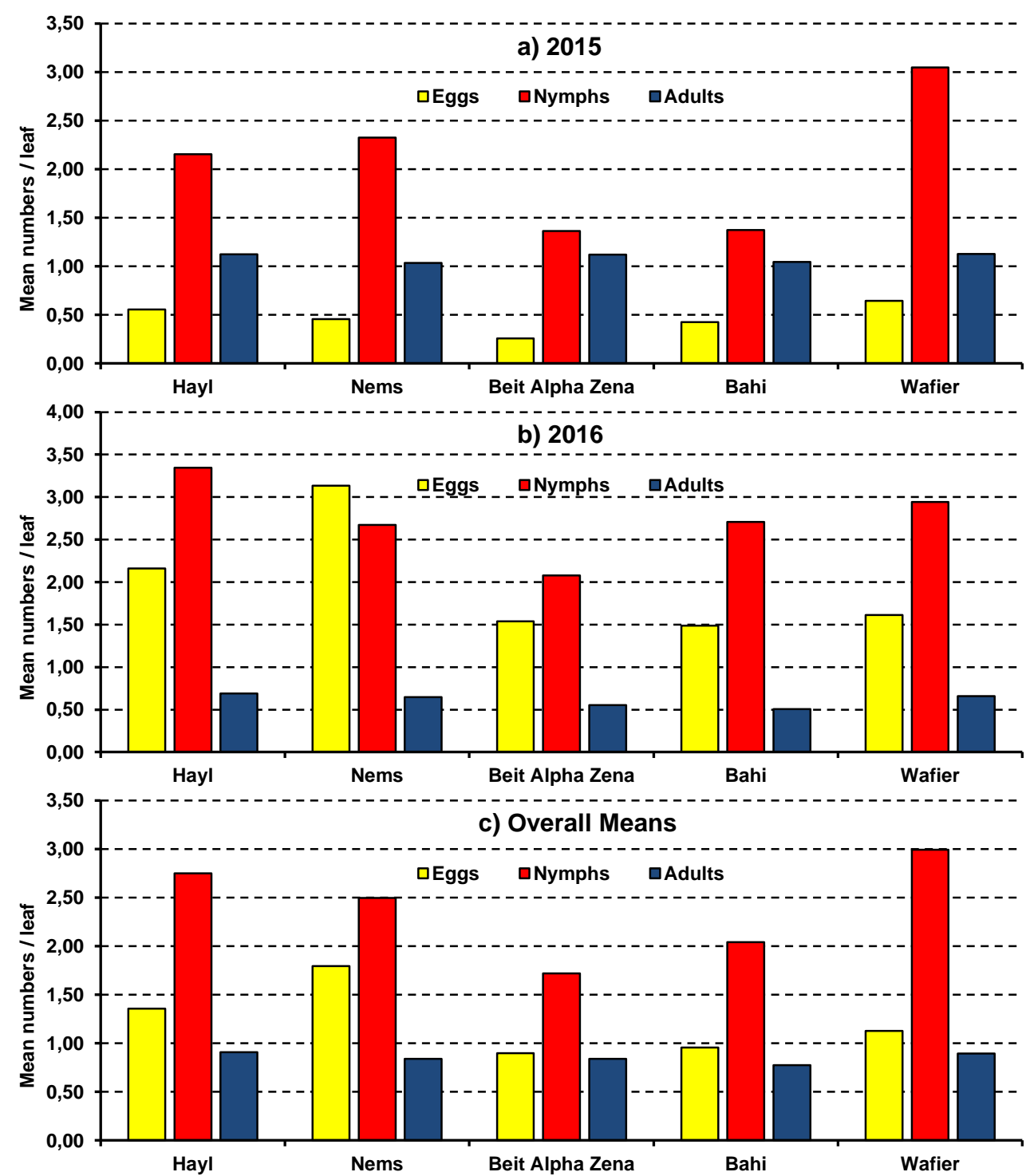

Fig. 2. Mean numbers of Bemisia tabaci eggs, nymphs and adults/leaf on five cucumber cultivars.

\section{b. Nymphs}

The presence of nymphs on all the cultivars was first observed on 7 September 2015 at the seedling stage. Nymph infestation of cucumber plants was moderately severe during the seedling period from 28 August to 13 September 2015 and at the beginning of plant 
flowering. The highest nymph peak occurred during September 2015 on all the cucumber cultivars with respective mean numbers of 9.83 and 4.98 nymphs/leaf on 7 September 2015 on Beit Alpha Zena and Bahi (Fig. 1). Hayl and Nems harboured high peaks (8.31 and 9.15 nymphs/leaf, respectively) on 10 September, and Wafier had the highest peak (9.35 nymphs/leaf) on 13 September 2015. Thereafter, nymph infestations declined, finally disappearing on 25 October 2015. One may infer from Figs. 1 and 2 that the overall levels of nymph infestations were the highest on Wafier, Nems and Hayl, and the lowest on Bahi and Beit Alpha Zena.

In 2016, nymph infestations were slightly higher than during the previous year with overall mean numbers of 3.34, 2.94, 2.71, 2.67 and 2.08 nymphs/leaf on the Hayl, Wafier, Bahi, Nems and Beit Alpha Zena cultivars, respectively (Fig. 2). Nymph populations fluctuated during the 2016 season, with the population peaks varying from one to three on all the cultivars (Fig. 1). Finally, the mean numbers of B. tabaci nymphs were concentrated on the seedling stage during both seasons on all the cultivars.

\section{c. Eggs}

Throughout the 2015 season, mean numbers of $B$. tabaci eggs were low on all the cultivars: <3 eggs/leaf. The highest mean numbers were 2.79, 2.19, 1.98, 1.89 and 1.73 eggs/leaf on Hayl, Wafier, Nems, Bahi and Beit Alpha Zena, respectively. The eggs disappeared during the three first inspections and between 13 and 28 October 2015 (Figs. 1 and 2). In 2016, egg numbers were higher than in 2015: the highest peak (>10 eggs/leaf) was recorded on all the cultivars except Nems and Bahi. The overall mean numbers of eggs/leaf laid on Nems, Hayl, Wafier, Beit Alpha Zena and Bahi were 3.13, 2.16, 1.61, 1.54 and 1.49, respectively (Fig. 2). Generally, the mean numbers of B. tabaci eggs, nymphs and adults were slightly higher in 2015 than in 2016 on all the cultivars.

\section{Influence of temperature and relative humidity on the $B$. tabaci population}

\section{a. 2015}

A non-significant positive relationship between the maximum temperature and the population density of $B$. tabaci eggs, nymphs and adults was recorded for all the cultivars except Beit Alpha Zena and Wafier, which exhibited a significant positive correlation (Table 1). Also, a non-significant positive correlation between the population of B. tabaci eggs, nymphs and adults and minimum temperature was found for all the cultivars, except for eggs on Beit Alpha Zena, which displayed a significant positive correlation (Table 1). 


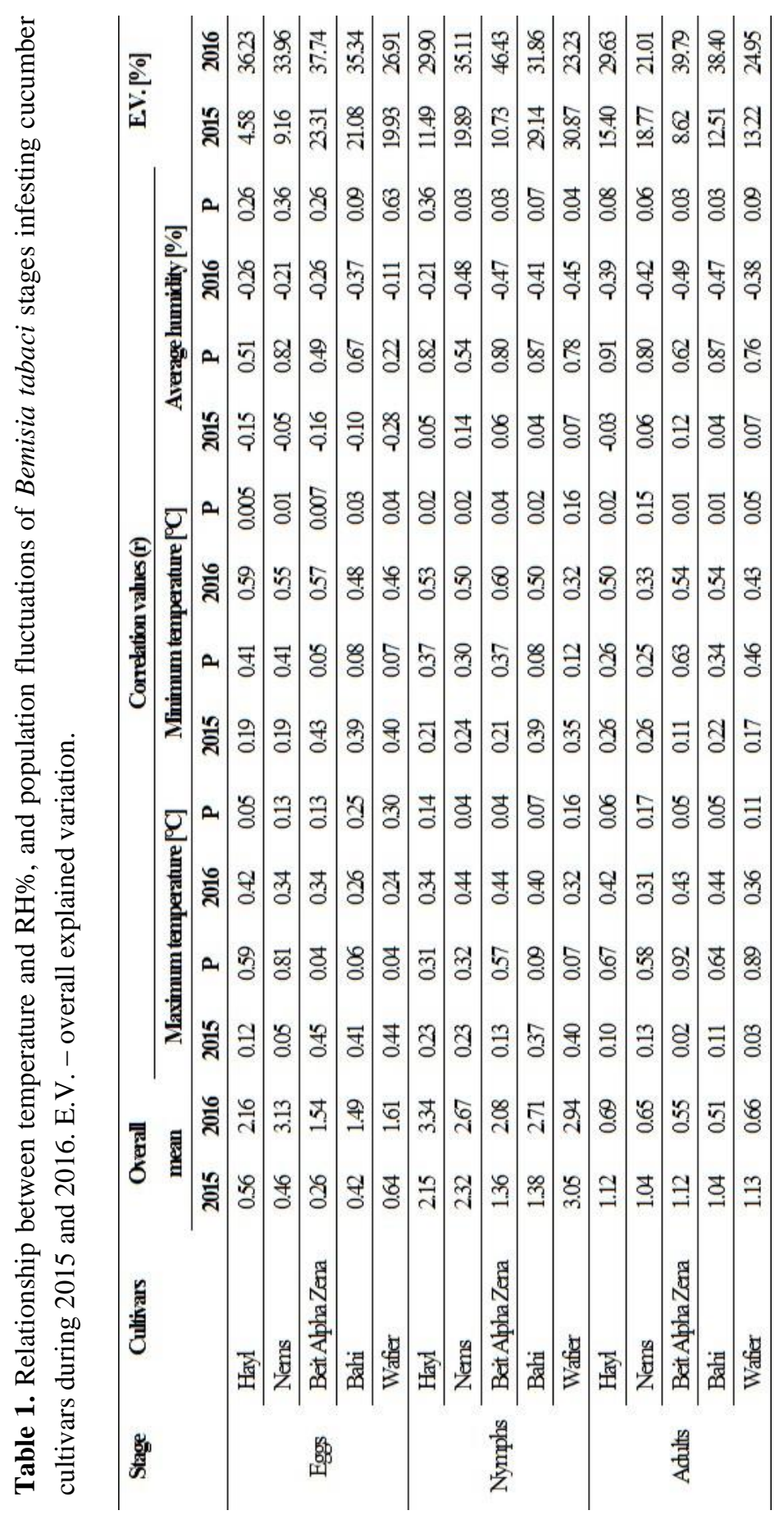


The relationship between the population fluctuation of B. tabaci eggs and average $\mathrm{RH} \%$ was insignificantly negative on all the cultivars. In contrast, there was a slight positive relationship between nymph populations and average $\mathrm{RH} \%$. In addition, the results showed a slight positive correlation for adults with all the cultivars, except for Hayl, for which, a slight negative correlation was reported (Table 1). The relationship between the collectively tested weather factors and the population densities of $B$. tabaci stages was expressed by calculating the overall explained variance (E.V. \%) on the five cucumber cultivars. The highest overall E.V. \% was $23.31 \%$ for eggs on Beit Alpha Zena, $30.87 \%$ for nymphs on Wafier and $18.77 \%$ for adults on Nems (Table 1).

\section{a. 2016}

The population density of $B$. tabaci stages and the maximum temperature was positively correlated during 2016 for all the cultivars (Table 1). Moreover, a positive but insignificant correlation was found between the population of $B$. tabaci nymphs and the maximum temperature on all the cultivars except Beit Alpha Zena and Nems, for which a significant correlation was recorded during 2016. For adults, the correlations with maximum temperature during 2016 decreased in the following order: Bahi, Beit Alpha Zena, Hayl, Wafier and Nems. For Bahi and Beit Alpha Zena this relationship during 2016 was significant (Table 1).

There was a simple, significant correlation between the average numbers of eggs and the average minimum temperature for all cultivars during 2016. With regard to the average numbers of nymphs and minimum temperature, a significant positive relationship was observed on all cultivars except Wafier, which exhibited an insignificantly positive relationship. Adult correlations were also significantly positive for all cultivars except Nems, for which the relationship was non-significant (Table 1). There were non-significant negative relationships between $\mathrm{RH} \%$ and egg numbers on all five cultivars. The correlation coefficient (r) between RH\% and nymphs showed an insignificantly negative relationship between average RH\% and adults on Nems, Hayl and Wafier throughout 2016. However, there was a significantly negative relationship between adults and average $\mathrm{RH} \%$ on Beit Alpha Zena and Bahi during 2016 (Table 1).

More than $30 \%$ of the explained variance (E.V. \%) was found between the collectively studied weather factors and B. tabaci egg populations for all the cultivars except Wafier during 2016. With regard to B. tabaci nymphs, the effect of the combined studied weather factors was the strongest on Beit Alpha Zena, whereas the weakest one was on Wafier (Table 1). 


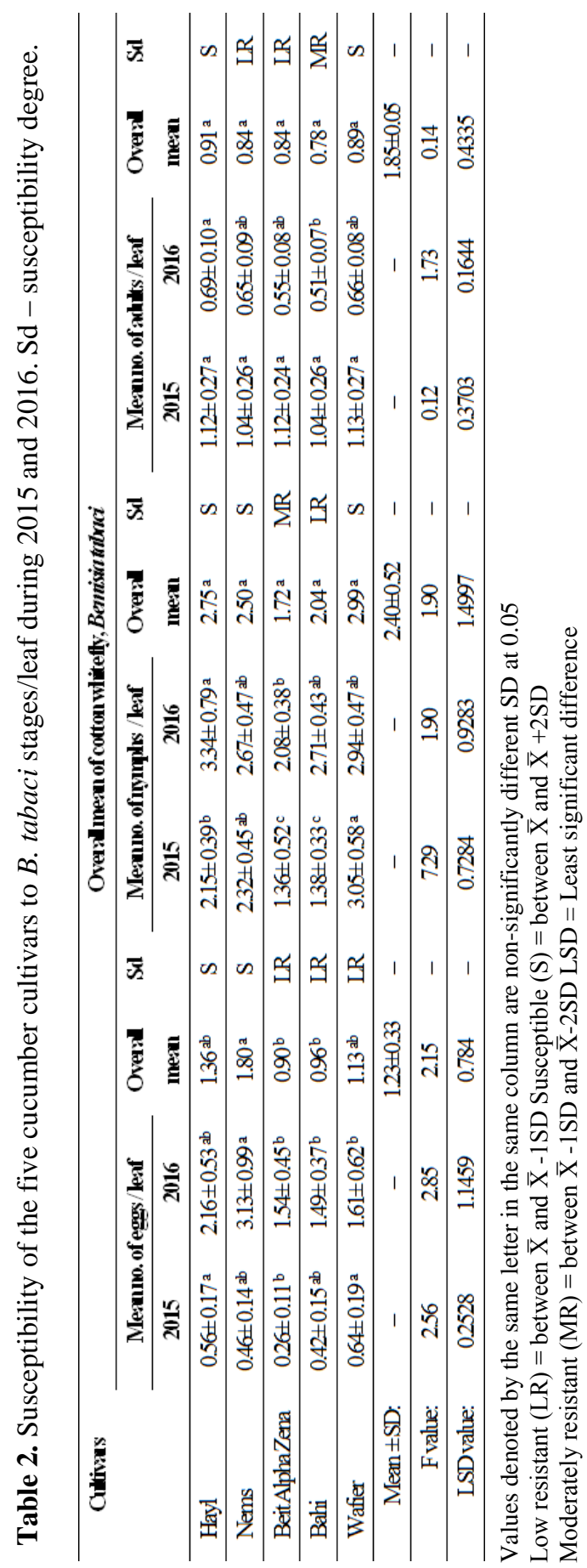




\section{Susceptibility of the five cucumber cultivars}

The data presented here showed significant differences between the five cucumber cultivars in both seasons, except for the adult stage, for which there were insignificant differences with the cultivars during 2015 (Table 2). The degree of infestation of B. tabaci eggs differed significantly among the five cultivars. In both seasons, the respective mean numbers of B. tabaci eggs/leaf on Hayl, Nems, Beit Alpha Zena, Bahi and Wafier were $0.56,0.46,0.26,0.42$ and 0.64 in 2015, and 2.16, 3.31, 1.54, 1.49 and 1.61 in 2016 (Table 2). The degrees of cultivar susceptibility could be grouped according to the LSD value for the overall mean of $B$. tabaci eggs into three classes: a) high - Nems, b) moderate - Hayl and Wafier, and c) low - Bahi and Beit Alpha Zena. The degrees of susceptibility of the cultivars were subdivided into 1) a susceptible group (S), harbouring high numbers of $B$. tabaci eggs (Hayl and Nems), and 2) a low resistant group (LR), supporting low numbers of this pest (Beit Alpha Zena, Bahi and Wafier) (Table 2).

The data presented in Table 2 indicate that the mean numbers of nymphs/leaf differed significantly among the five cucumber cultivars during 2015 and 2016, whereas the differences among them were insignificant when compared with the overall mean numbers of nymphs/leaf in both seasons. In descending order, the respective B. tabaci nymph infestations in 2015 were 3.05, 2.32, 2.15, 1.38 and 1.36 nymphs/leaf, on Wafier, Nems, Hayl, Bahi and Beit Alpha Zena, while the corresponding figures for 2016 were 3.34, 2.94, 2.71, 2.67 and 2.08 nymphs/leaf on Hayl, Wafier, Bahi, Nems and Beit Alpha Zena (Table 2).

The degrees of susceptibility of the cultivars in both seasons were: susceptible (S) Hayl, Nems and Wafier, low resistant (LR) - Bahi, and moderately resistant (MR) - Beit Alpha Zena (Table 2).

\section{DISCUSSION}

In the present study, the highest peak of eggs of $>10$ eggs/ leaf was detected on all the cultivars except Nems and Bahi. The mean numbers of B. tabaci stages were slightly higher in 2015 than in 2016 for all the cultivars. These results are in agreement with those found by EL-SERwIY et al. (1984) and HEGAB et al. (1989), who reported that the infestation of different cucurbitaceous crops with $B$. tabaci was high during summer (July-October) but relatively low during spring (March-June). They also found that the incidence of $B$. tabaci adults was high through September and October on cucumber cultivars, but that nymphs were present during October and November. Moreover, SHALABY et al. (2013) reported a high infestation of whitefly occurring from September to March 2009 and a lower one from April to August. 
On the other hand, three peaks of B. tabaci were found on summer cucumber plantations during the second week of May, the first week of June and throughout July 1993 (AHMED 1994). Cantaloupe plants were infested with B. tabaci from seedling to harvest (May-July 1996) (KAMEL et al. 2000), the infestation increasing progressively from mid-June until the end of July 1996. HEGAB (2017) noted whitefly populations on three cucumber varieties in July 2016. Different crops, such as melon, cucumber, pumpkin and squash, infested by B. tabaci, were reported in India by LANJAR et al. (2012), the largest population being recorded on cucumber followed by melon, squash, pumpkin and water melon. In our study, high whitefly peaks occurred during September and October, and the lowest one in November during both seasons. Therefore, we need to manage this whitefly in the seedling stages in all September cucumber cultivations in order to reduce transmission of the whitefly virus to cucurbitaceous and other vegetable crops in Egypt.

Both temperature and relative humidity were common abiotic variables affecting the development of $B$. tabaci, followed by other factors like the growth condition of food plants. Our findings were comparable to those obtained by ADAM et al. (1997), who reported a significant positive correlation between both temperature and relative humidity and B. tabaci populations on cucumber plants in a plastic foil covered greenhouse. Populations of whitefly increased with increasing temperatures and decreasing relative humidity (MAKLAD et al. 2012, HANAFY et al. 2014). A non-significant effect of temperature and rainfall was recorded on the occurrence of $B$. tabaci on cucumber by LEITE et al. (2006). El-LAKWAH et al. (2011) indicated that the mean temperature had a significant effect on B. tabaci populations, but that $\mathrm{RH} \%$ had no significant effect. AMMAR \& ABOLMAATY (2016) found that the maximum temperature displayed an insignificantly positive effect in 2015 , but that the minimum temperature had a significantly positive on B. tabaci (eggs and nymphs) during 2016. They also found that RH\% had an insignificantly negative effect on $B$. tabaci populations. We demonstrated that the combination of temperature and $\mathrm{RH} \%$ was an important factor affecting insect development. In Egypt, the warm and humid conditions prevailing from the first week of September until the last week of October are more suitable for insect development. The progressive increase in cucumber pest populations in these months suggests the need for initiating control of this pest in the seedling and flowering stages before it reaches its peak.

In the present work, we found three degrees of susceptibility in both seasons: susceptible (S) - the Hayl, Nems and Wafier cultivars, low resistant (LR) - Bahi, and moderately resistant (MR) - Beit Alpha Zena. For adults, non-significant differences were found among the cultivars throughout 2015, whereas the difference was significant in 2016. These results agree with those recorded on cucumber cultivars in Egypt by AHMED (1994), HANAFY (2004) and EL-LAKWAH et al. (2011). They evaluated six cucumber varieties for susceptibility to B. tabaci infestation, depending on overall mean numbers. In field trials, 
(2013) also evaluated the susceptibility of four cucumber varieties to EL-GARHY infestations of second instar nymphs of B. tabaci. The differences between the mean numbers of $B$. tabaci stages/leaf on cucumber cultivars were recorded to determine the susceptibility of common cultivated cucumber cultivars to B. tabaci infestation in Egypt (DAWOOD 1999). Similar, comparable findings were reported by METWALLY et al. (2013) on cantaloupe cultivars, recording significant differences in its susceptibility to $B$. tabaci infestation.

The cucumber cultivars investigated in our study differed from those of previous authors in Egypt. The geographical location investigated also differed in structure from those in other previous studies; this may be an important factor in evaluations of infestations by this pest. In our study, we manipulated the degrees of susceptibility between cucumber cultivars depending on the overall mean number $\overline{\mathrm{X}}$ of all cultivars and SD according to CHIANG \& TALEKAR (1980), but earlier authors like AHMED (1994), DAWOOD (1999), HANAFY (2004) and EL-LAKWAH et al. (2011) and El-Garhy (2013) classified the degrees of susceptibility depending only on the least significant differences between other cucumber cultivars according to Fisher's test (F-test). In the light of significant climatic changes in Egypt, the present results will be of significant value in this country. These degrees of susceptibility are therefore important in order to point out that insect infestation rates must refer to the degree of resistance of each cultivar.

\section{CONCLUSION}

This study confirmed that high infestation peaks of whitefly occurred throughout September and October during both seasons. Fluctuations in the populations of $B$. tabaci stages were affected by warm and humid conditions. The degrees of susceptibility refer to the degree of resistance of each cultivar against insect infestation, which will aid the setting up of whitefly management programmes in this country.

\section{REFERENCES}

AdAm M.K, Bachatly M.A., Doss S.A. 1997. Population of the whitefly Bemisia tabaci (GenN.) (Homoptera: Aleyrodidae) and its parasitoid Eremocerus mundus MERCEC (Hymenoptera: Aphelinidae) in protected cucumber cultivations. Egyptian Journal of Agriculture Research, 75 (4): 939-950.

AdKins S., WebB S.E., Achor D., Roberts P.D., BAKer C.A. 2007. Identification and Characterization of a Novel Whitefly-Transmitted Member of the Family Potyviridae Isolated from Cucurbits in Florida. Phytopathology, 97 (2): 145-154. 
AHMED M.A. 1994. Differences in susceptibility of six cucumber cultivars to infestation by Aphis gossypii GLOV., Tetranychus urticae and Bemisia tabaci as correlated to protein and amino acid contents of leaves. Annals of Agricultural Science Moshtohor, 32 (4): 2189-2194.

Ammar M.I., AbolmaAty S.M. 2016. Effect of Different Colors Mulch on Population Density of Some Pests Infesting Cucumber Plants and on Cucumber Yield. Egyptian Academic Journal of Biological Sciences A (Entomology), 9 (4): 153-162.

BASU A.N. 1995. Bemisia tabaci (Gennadius): Crop Pest and Principal Whitefly Vector of Plant Viruses. Oxford and IBH Publishing, New Delhi, Bombay, Calcutta, India.

ChIANG H.S., TALEKAR N.S. 1980. Identification of Sources of Resistance to the Beanfly and Two Other Agromyzid Flies in Soybean and Mungbean. Journal of Economic Entomology, 73 (2): 197-199.

DAwOOD M.Z. 1999. Susceptibility of certain commonly cultivated squash and cucumber cultivars to Bemisia tabaci (GeNn.) (Homoptera: Aleyrodidae) in Beni-Suef Governorate. Egyptian Journal of Agricultural Research, 77 (3): 1075-1080.

EL-Garhy S.M.M. 2013. Evaluation of Some bio insecticides against Bemisia tabaci (GENN.) and effect on yield component of cucumber. Egyptian Journal of Agricultural Research, 91 (3): $813-824$.

El-Lakwah F.A., Abd-El Wahab H.A., Kattab M.M., Azab M.M., El-Ghanam M.S. 2011. Population dynamics of some pests infesting nili cucumber plantations in relation to certain ecological factors. Egyptian Journal of Agricultural Research, 89 (1): 137-153.

El-Serwiy S., El-Haidari H., SaAd A. 1984. Population density of the whitefly Bemisia tabaci (GENN.) (Homoptera: Aleyrodidae) on fall cucumber in Iraq. Journal of Agriculture, 3: 78-87.

HANAFY A.R.I. 2004. Studies on the most important cucumber pests in the open field and suitable control programs. Ph.D. Thesis. Faculty of Agriculture, Moshtohor, Zagazig University, Zagazig, Egypt.

HANAFY A.R.I., BAIOMY F., TANTAWY M.A.M. 2014. Comparison between the infestation rate of certain pests on cucumber and kidney bean and its relation with abiotic factors and anatomical characters. Egyptian Academic Journal of Biological Sciences, 7 (2): 63-76.

Hegab A.M., Helaly M.M., HaSSANEIN S.S.M. 1989. Survey and seasonal abundance of leaf hopper species (Homoptera: Cicadellidae) infesting certain cruciferous and cucurbitaceous vegetable plants in newly reclaimed sandy areas at Salhia district, Egypt. Zagazig Journal of Agricultural Research, 16: 109-121.

Hegab M.A.M 2017. Effect of Different Varieties of Cucumber Plants on the Attractive of some Homopterous Insect Pests. Journal of Plant Protection and Pathology, 8 (12): 641-645.

Jianyu Z., Yanqiang L., Lian D., Shuangshuang Y., Meiling L., Li J., Wensheng Z., Qian W., LiYing Y., RenYi L., XiaOlan Z. 2016. Phloem transcriptome signatures underpin the physiological differentiation of the pedicel, stalk and fruit of cucumber (Cucumis sativus L.). Plant and Cell Physiology, 57 (1): 19-34.

KAMEl M.H.M., El-SherIF S.I., El-Dabi R.M. 2000. Population fluctuation of three sap sucking insects on cantaloupe summer plantations. Egyptian Journal of Agricultural Research, 78 (3): $1041-1048$ 
Lanjar A.G., Baloch N., Rustamani M.A., Lohar M.K., Solangi A.W. 2012. Preferential distribution of whitefly, Bemisi tabaci GENN. on cucurbit and non-cucurbit crops. Sindh University Research Journal (Science Series), 44 (3): 381-384.

Leite G.L.D., Picanco M., Guedes R.N.C., Ecole C.C. 2006. Factors affecting the attack rate of Bemisia tabaci on cucumber. Pesquisa Agropecuaria Brasileira, 41 (8): 1241-1245.

Maklad A.M.H., AbolmaATy S.M., Hassanein M.K., AbD El-Ghafar N.Y. 2012. Impact of type of greenhouse cover sheets on certain major cucumber pests under protected cultivation. New York Science Journal, 5 (7): 19-24.

Mansour A., Al-Musa A. 2008. Cucumber Vein Yellowing Virus; Host Range and Virus Vector Relationships. Journal of Phytopathology, 137 (1): 73-78.

Metwally S.A.G., ShoukRy I.F., Younes M.W.F., ABD-Allah Y.N.M. 2013. The susceptibility of certain cantaloupe cultivars to different three pests infestation in Qualybia Governorate, Egypt. Egyptian Journal of Agricultural Research, 91 (1): 151-167.

MoHAmed M.A. 2012. Impact of planting dates, spaces and varieties on infestation of cucumber plants with whitefly, Bemisia tabaci (GENN.). Journal of Basic and Applied Zoology, 65 (1): $17-20$.

Moreno V., Gomez Aguilera J.L., Gueraude Arellano C., Roig L.A. 1993. Preliminary screening of cucurbits species for Bemisia tabaci GENN. whitefly resistance. Reports of Cucurbit Genetics Cooperative, 16: 87-89.

SAS 2003. SAS/STAT User's guide, SAS version 9.1. SAS Institute, Inc, Cary, NC, USA.

Shalaby F.F., Ali F.A., Hafez A.A., SAAD H.M. 2013. Planting date in relation to insect and animal pests attacking cucumber plants under protected cultivation at Giza governorate. Egyptian Journal of Agricultural Research, 91 (4): 1347-1360.

TANTAwI M.A.M. 1995. Monitoring of Bemisia tabaci (GENN.) population on certain crops and its control. M.Sc. Thesis, Faculty of Agriculture, Cairo University, Giza, Egypt.

Van Doorn A., De Vries M., Kant M.R., Schuurink R.C. 2015. Whiteflies glycosylate salicylic acid and secrete the conjugate via their honeydew. Journal of Chemical Ecology, 41(1): 52-58.

Received: 8 September 2019

Accepted: 9 October 2019 